Article

\title{
Assuring SME's Sustainable Competitiveness in the Digital Era: A Labor Policy between Guaranteed Minimum Wage and ICT Skill Mismatch
}

\author{
Alexandru Avram ${ }^{1, *}$, Marco Benvenuto ${ }^{2}$, Costin Daniel Avram ${ }^{3}$ and Ginevra Gravili ${ }^{2} \mathbb{C}$ \\ 1 Department of Finance, Faculty of Economics and Business Administration, West University of Timisoara, \\ 300115 Timisoara, Romania \\ 2 Department of Economics, University of Salento, 73100 Lecce, Italy; marco.benvenuto@unisalento.it (M.B.); \\ ginevra.gravili@unisalento.it (G.G.) \\ 3 Department of Economics, Accounting and International Affairs, Faculty of Economics and Business \\ Administration, University of Craiova, 200585 Craiova, Romania; avram.costin@ucv.ro \\ * Correspondence: alexandru.avram@e-uvt.ro; Tel.: +40-256-592-505
}

Received: 29 March 2019; Accepted: 15 May 2019; Published: 22 May 2019

\begin{abstract}
The aim of this paper is to analyze the real impact of ICT (Information and Communications Technology) skills mismatch on SME's (small and medium enterprises) sustainable competitiveness in the presence of a guaranteed minimum wage. As part of public policies-the minimum wage needs to maintain a balance between increasing employment and not being a burden for the companies, leading them to bankruptcies, especially in times of disruptive change, in which economies have to be more resilient. The rapid progress in information and communication technologies has dramatically redefined rising unemployment as a result of skills mismatch. This paper aims to understand, on the one hand, whether there is a match between the supply demand of ICT skills, and how increasingly powerful digital technologies affect the skills, jobs, and demand for human labor. On the other hand, it aims to understand whether increasing productivity and a fair minimum wage could be an integrated approach for stimulating SME's in increasing sustainable competitiveness.
\end{abstract}

Keywords: ICT skills mismatch; guaranteed minimum wage; SME's sustainable competitiveness; employment; public policies

\section{Introduction}

This paper focuses on the relation among ICT (Information and Communications Technology) skills mismatch, minimum wage, and SME's (small and medium enterprises), sustainable competitiveness, in order to fill research gaps existing in literature.

Rapid technological development is imposing the acquisition of new skills to respond to the current and future needs of firms and labor markets [1], changing organizational processes and individual job profiles [2]. Consequently, the world is moving towards a digital "people-driven economy" [3,4], in which attracting and retaining human resources have become strategic imperatives [5]. In this context, being able to capture the talents ("war for talent") and "matching workers' skills to the most appropriate jobs within the firms" [6] are becoming real priorities for companies, creating an "economic value of a magnitude that few other economic processes can" [7].

The literature, from a managerial perspective, highlights that in the labor world, ICT skill mismatch (a lot of workers have jobs that do not commensurate with their background, or they are overeducated or undereducated) is causing important implications at both strategic, and managerial and operational levels [8-11]. For the strategic level, a skill mismatch implies a new policy formulation and overall goal setting, with specific focus on the positioning of the organization in its environment. 
At the operational level, the day-to-day management of the organization is carried out under the umbrella of the managerial plans. Consequently, a managerial level mismatch requires the study and identification of new adequate skills for resources, which are the information, knowledge and capabilities that the company needs. In this framework, a critical factor is the guaranteed minimum wage. A concept born for social assistance, which could yet shift the decision of the unemployed, as rational choice, between spending free time as a free-rider on welfare, or readapting skills in order to be employed. There is a general consensus among economists for the provision of social protection-meaning putting in place various instruments for assuring income security, which is an economic and social necessity [12]. Indeed, the rational choice for spending free time as a free rider or for accepting the guaranteed minimum wage (the higher it is, the bigger the incentive to work) for the skills it requires (the lower they are, the bigger the incentive the employment barriers), could create an inactivity trap [13-16]. The danger is that a generous social assistance "may lock low-skilled workers into persistent low-wage employment", generating a potential disincentive to work $[17,18]$.

A minimum wage is part of the social policies meant to reduce disparities and to decrease poverty, being welcomed by most economists [19]. As a social policy that aims to increase employment and reduce poverty, an increase in the minimum wage could change the person's decision to spend his/her free time to instead working, because of the new satisfactory salary level. However, the minimum wage is not an arbitrary value that can be set freely by the government based on electoral promises, it has to keep in mind basic economic notions such as productivity and inflation. An increase in the minimum wage that is disconnected from productivity can lead to bankruptcies and inflation. An arbitrary value for the minimum wage that is set too high could have the opposite effect on public policy aimed at increasing employment, ultimately leading to bankruptcies and unemployment.

Despite this, currently, little research has been conducted to assess the real impact of ICT skill mismatch on SME's sustainable competitiveness in the presence of a guaranteed minimum wage, and its impact on employment.

In this paper, sustainable competitiveness is considered as an umbrella that combines the interests that underlie sustainable development and competitiveness. It represents the appropriate context for considering the relation between public policies and competitiveness, and for this reason, the purpose of this article is to explore the following:

1. The dynamics that link ICT skills mismatch and SME's sustainable competitiveness and economic growth in the technological era [20], to observe their effects for the labor market in general, and for employment in the world, in particular, in European countries;

2. The impact of a guaranteed minimum wage in the European labor market (without Croatia because of a lack of data for the period of 2007-2015), using a longitudinal model to analyze the described effects with an explorative investigation in Romania.

Starting from these results, we will identify whether there is a relationship among ICT skill mismatch, SME's competitiveness, and employment.

Hypothesis 1 (H1). is that ICT personnel and their tertiary education for ICTs (adding skills) have a positive effect on jobs creation and employment.

In addition, we are setting up our second hypothesis, comprised of Hypothesis 2.1 and 2.2, which is based on the relations between the guaranteed minimum wage, SME's sustainable competitiveness, and employment.

In Hypothesis 2.1 (H2.1). we are assuming that an increase in ICT skills will encourage employment and stimulate sustainable growth, and thus the competitiveness of SMEs.

In Hypothesis 2.2 (H2.2). we are assuming that the ICT skills will have a negative impact on social exclusion by the creation of jobs. 
Our Hypothesis 3 (H3). supposes that there is the positive impact of the minimum wage on job creation and employment.

If this thesis were verified, we would demonstrate a new and original relationship between the increasing ICT education and decreasing risk of social exclusion and poverty, in the presence of a guaranteed minimum wage for achieving competitiveness of firms, by using a VAR (Vector autoregression) model. The present paper is organized as follows. After the Introduction (Section 1), Section 2 highlights the current state of knowledge on skills mismatch, guaranteed minimum wage, and SME's competitiveness. Section 3 describes the research method used to analyze the European labor market and the Romania' case study, while the empirical findings in Section 4 show the implication of ICT skills on employment and of the impact of a guaranteed minimum wage on employment. In Section 5, there are the conclusions, followed by the implications for research in Section 6.

\section{Current State of Knowledge}

\subsection{ICT Skills Mismatch}

Skills mismatch, considered initially from researchers [21] as a temporary phenomenon, was analyzed diffusely from the late 1980s, starting the debate on the importance of job characteristics in determining wages.

In general, the term skills mismatch can describe situations in which workers' skills exceed or lag behind those employers seek. It highlights a non-conformity among "individuals' preferences, interests, needs, skills, demographic characteristics, and required qualifications, physical and mental demands, stability, compensation, benefits, and locations of the jobs they do" [22]. The literature identifies skills mismatch as one of the three dimensions of job mismatch, namely: qualification mismatch, skills mismatch, and field-of-study mismatch [23]. In particular, the "qualification mismatch compares a worker's acquired qualifications with those required by his/her current job", while "field-of-study mismatch analyses the level of match between an individual's field of study and his/her job" [23]. The skills mismatch dimension involves various contributions that could offer useful insights. Specifically, in the last years, studies on skills mismatch are focusing on the effects that technology, communication, work systems, organizational processes, and all aspects of life have had on skills. In this background, in which information and knowledge are rapid, skills mismatch in the workplace has important empirical implications [24-29].

In wider terms, this could be defined as a phenomenon that occurs when workers have not got the skills needed in order to carry out successfully the required job tasks. It is a very broad concept and includes a variety of measures. Commonly, the literature identifies different categories of skill mismatch, as follows:

(i) Vertical mismatch [30-32]. The level of education or qualification is less or more than required, measured in terms of being under-skilled or having a skill deficit, or being over-skilled or having a skill surplus for a required skill. An ICT skill deficit can be an obstruction for firms regarding the challenges that disruptive technologies impose. Therefore, companies that do not adapt to the new skill technological reality could lose their competitiveness.

(ii) Horizontal mismatch $[30,32,33]$. The skills are inappropriate for the job. Individuals who adapt quickly to new technological work demands have a greater chance for re-employment. Instead, hesitant workers could have more difficulties, and it is probable that they have to accept positions that are not in line with their skills [34]. In fact, ICT skill underutilization, due to a lack adoption of new skills by firms, could result in an atrophy of the workers' skills, and a productivity and economic growth decrease [31-35].

(iii) Skill gaps [31,36-38]. When the demand or supply for a particular type of skill exceeds the supply/demand of people with that skill-usually measured in terms of unfilled and hard-to-fill vacancies. ICT skill shortages occur when a company cannot find suitably qualified workers, 
and under-skilled workers man vacant posts. This could have negative consequences on economic growth, because skill shortages slow the rate at which more efficient technologies and approaches to work organization are adopted [39].

(iv) Skill obsolescence (skills previously used in a job are no longer required and/or skills have deteriorated over time) [40,41]. According Allen and de Grip [41], there are two models of skill obsolescence, namely: the dynamic model and the static model. In the first model, workers are in dynamic companies where ICT job contents constantly change. In this context, companies invest so as to overcome obsolescence, so there is "a constant research of the balance between shifts in the skills requirements of the job and the updating of skills". In the static model, skill obsolescence causes unemployment, because this approach assumes that an employee's ICT skill level remains moderately stagnant throughout their career.

This literature has come to light, for which recent changes require the optimization of ICT skills to encourage worker's satisfaction, SME's competitiveness, and economic growth [42-45].

\subsection{Guaranteed Wage on Labour Market}

The guaranteed minimum wage was implemented, for the first time, in the United States in 1938, during the Roosevelt administration. Defined as "the statutory wage established legally to guarantee to the employees from disadvantaged categories an income that corresponds to the minimum amount for subsistence determined in relation to the given social environment", the guaranteed minimum wage for payment has become a reality since the first half of the 20th century in most countries of the world [46]. In Europe, for example, most states have regulated guaranteed minimum wages after negotiations between the government and social partners [47].

The introduction of a guaranteed minimum wage, as well as its level over time, has prompted the attention of researchers, often encouraging positions tributary to some currents of thought, referring to Keynesism or neo-liberalism, and producing literature sharing both pros and cons.

The literature in favor of introducing a guaranteed minimum wage and adjusting it according to socio-economic conditions point out some positive aspects. Sutch, in 2010 [48], for example, noticed that the guaranteed minimum wage promotes continuous education and training, which has as the effect of increasing skill levels and labor productivity, and, on this basis, increasing the average wage in the economy. Following the same logical pattern, Fox, in 2013 [49], reported a relationship between raising the guaranteed minimum wage and raising the standard of living by reducing the number of people affected by poverty, leading to a decrease in public spending on social programs, and budget transfers to people affected by poverty. Other authors, such as Freeman, in 1994 [21], concluded that the guaranteed minimum wage stimulates consumption, which leads to an increase in the global demand, which determines a growth in the number of jobs available, and ultimately stimulates employability. It has emerged, moreover, that raising the guaranteed minimum wage forces companies to rethink technological processes, intensify the automation of work processes as much as possible, and thus increase the efficiency of industrial production by reducing wage costs [50]. A legally established guaranteed minimum wage per economy causes employees to specialize and access better-paid jobs [51].

The specialized literature also highlighted a number of negative aspects related to the introduction of the guaranteed minimum wage and its increase, according to the political agenda. Abbott, in 2000 [52], found that increasing the guaranteed minimum wage hurries low-efficiency entities into insolvency, and generates additional expenses on unemployment benefits, thus generating a series of macroeconomic imbalances. Increasing the guaranteed minimum wage affects, to a larger extent, small and medium enterprises more than large companies and multinational companies [53]. This is accompanied by long-term unemployment growth [54], but also a constant inflationary pressure generated by companies' pricing policy meant to maintain high profit margins [55]. The rise of guaranteed minimum wage generates complacency behavior by stimulating low-skilled jobs [56], with distortive effect on the rational choices of workforce by disappearance of the motivation to prepare 
for accessing a better-paid job in a longer time horizon. The effect of this behavior is reflected in a slowdown in labor productivity and therefore economic growth.

Thus, we observe that the literature in favor of a guaranteed minimum wage takes into account that it can encourage a decrease in unemployment by stimulating employment. However, a minimum wage at a high level will determine unemployment by increasing production costs and generating bankruptcies through non-competitiveness for small- and medium-sized enterprises with low efficiency, but it will have a high share of participation in the national economy.

\subsection{ICT Skills Mismatch, Guaranteed Minimum Wage, and SME's Competitiveness}

Fostering innovation by ICT and SME's sustainable competitiveness are by no means mutually exclusive [57]. Most studies regarding this issue [58,59] have identified that innovation is positively correlated with firm growth in the short- and long-run. A literature analysis highlights that innovation by ICT can lead to economic growth in three important ways. First, innovation gives companies a competitive advantage, which can translate into increasing exports and stimulating the employment effects in the short term. Second, innovation's consequences translate to a virtuous cycle of expanding employment, that is, the emergence of information technology drives sustainable economic growth, stimulating hundreds of thousands of newly created jobs [60], which, in caeteris paribus conditions, lead to additional job growth in supporting industries for recognizing and evaluating employee benefits [61]. Finally, when innovation generates higher productivity, it also generates increased wages and lower prices, and in caeteris paribus conditions, is expanding domestic economic activity and creating jobs [62].

In this scenario, it is very important how the company's choices and the government's policies are correlated. In the literature there are two main different approaches (Figure 1), namely: wage led growth [63,64] and capital led growth [65].

In this regard, Table 1 shows that wage led growth policy (pro-labor) has results, such as a strong increase of wages and lower wage dispersion, while pro-capital distributional policy has a lower share of wages in total expenditures and higher dispersion.

Table 1. Pro-capital and pro-labor distributional policies.

\begin{tabular}{|c|c|c|c|}
\hline \multirow{2}{*}{ Policies/Resuts } & \multicolumn{3}{|c|}{ Distributional Policies } \\
\hline & Pro-Capital & Pro-Labor & Other Factors \\
\hline Policies & $\begin{array}{l}\text { No guaranteed minimum wage } \\
\text { Low bargaining power of } \\
\text { collective workers' associations } \\
\text { Wage moderation }\end{array}$ & $\begin{array}{l}\text { Increase of guaranteed minimum wage } \\
\text { Stronger bargaining power of collective } \\
\text { workers' associations }\end{array}$ & $\begin{array}{l}\text { Technological } \\
\text { innovations } \\
\text { Globalization } \\
\text { Financialization }\end{array}$ \\
\hline Results & $\begin{array}{l}\text { Weak increase of wages } \\
\text { Lower share of wage in total } \\
\text { expenditures } \\
\text { Higher wage dispersion }\end{array}$ & $\begin{array}{l}\text { Strong increase of wages } \\
\text { Stable or increasing wage share in total } \\
\text { expenditures } \\
\text { Lower wage dispersion }\end{array}$ & \\
\hline
\end{tabular}

The wage led growth theory starts from the premise that, during the last decades, the wages growth did not keep up with the increase of productivity, a situation that led to the period with the highest income inequality. During the past decade, the European economy was stimulated by a capital led growth approach, so, according to Stockhammer [65], the companies did not increase wages proportionately to the increase in ICT workers' skills and their productivity.

Polarizing revenue distribution and lowering the share of wage costs plays an important role in perpetuating unequal firm growth. Thus, a salary-based policy can promote stable growth. In these scenarios, the government can intervene easily by the introduction of a guaranteed minimum wage, stimulating a wage led growth economy, done on the expense of a profit led growth. 
We consider that a strategy of wage led growth, starting with the guaranteed minimum wage, must be correlated with the diminishing of skills mismatch for optimum results.

This strategy could lead to diminishing ICT skills mismatch, increased employment, lower social exclusion, and economic growth.

\section{Research Methodology}

The complexity of the thematic area has led us to constitute a longitudinal model to analyze the effects of ICT skills mismatch and the guaranteed minimum wage on SME's competitiveness and economic growth. To highlight the disparities of the ICT mismatch between the demand and supply of jobs, it is important to see whether the EU labor market is Keynesian or neoclassical

Among all of the countries analyzed, a specific situation is emerging in Romania. Romania is an upper-middle- to high-income country and it has one of the lowest unemployment rates in the EU (4.9\% at a national level at the end of December 2017, and 4.2\% in December 2018). Romania has increased the guaranteed minimum wage approximately 3.5 times over 10 years (from 117 Euro in 2007 to 409 Euro in 2018), and had the highest economic growth in the EU in 2017, at 6.9\%. Moreover, considering that Romania has one of the lowest productivities in the EU (about $60 \%$ of the EU average), the Romanian companies are complaining about a lack of skilled workforce in the context of one of the highest ratios of welfare personnel to employment in the EU. Consequently, it has in the same time both a Keynesian and neoclassical labor market such as at the EU level. For this reason, we have chosen to focus the study on Romania's labor market, one of the most dynamic ICT markets in the European Union, using two OLS (Ordinary Least squares)-type simple regressions.

\subsection{An Overview of the Labor Market in European System}

We consider that a Keynesian labor market is where the job supply is insufficient and people are job seeking, but they lack the opportunities, thus the demand is clearly higher than the supply. A neoclassical type is one in which potential employees, currently without a job, have to make a rational choice between taking advantage of their spare time or working for a salary, while determining the minimum level of income they shall accept.

A guaranteed minimum wage will create distortions in the choices of the unemployed, leading to a reduction in unemployment based on the rational choice of the unemployed to get a job.

It is very important to identify the type of unemployment that exists in the EU, as each type of unemployment requires specific measures and treatments. Keynesian type-based unemployment will require investment growth and facilities granted to employers, while neoclassical unemployment will have to provide incentives to the unemployed who are still finding the job offers in the economy unattractive, some preferring a minimum guaranteed income at the expense of a salary that requires 40 hours of weekly work.

Of course, countries can experience both types of unemployment at the same time, having regions with Keynesian unemployment and regions with neoclassical unemployment.

A generalization of the type of unemployment a country experiences could be misleading, with it being more correct to assert that the unemployment is structural or frictional. However, for our case studies that are handling public policies, it is important to identify the types of labor public policies that can tackle the labor market challenges. Structural or frictional unemployment is a result of inadequate labor market policies. Therefore, once the type of labor market is identified, the decision makers can tailor adequate labor policies as being important to establish the realism of the hypothesis and the quality of the decision makers' vision.

However, even though the unemployment rate at the EU 28 level was 7.7\% at the end of 2017, and $9.1 \%$ at the Euro Area, the job vacancy rate in the EU is decreasing, being at $2.3 \%$ in the EU 28 , as we can see in Figure 1. 


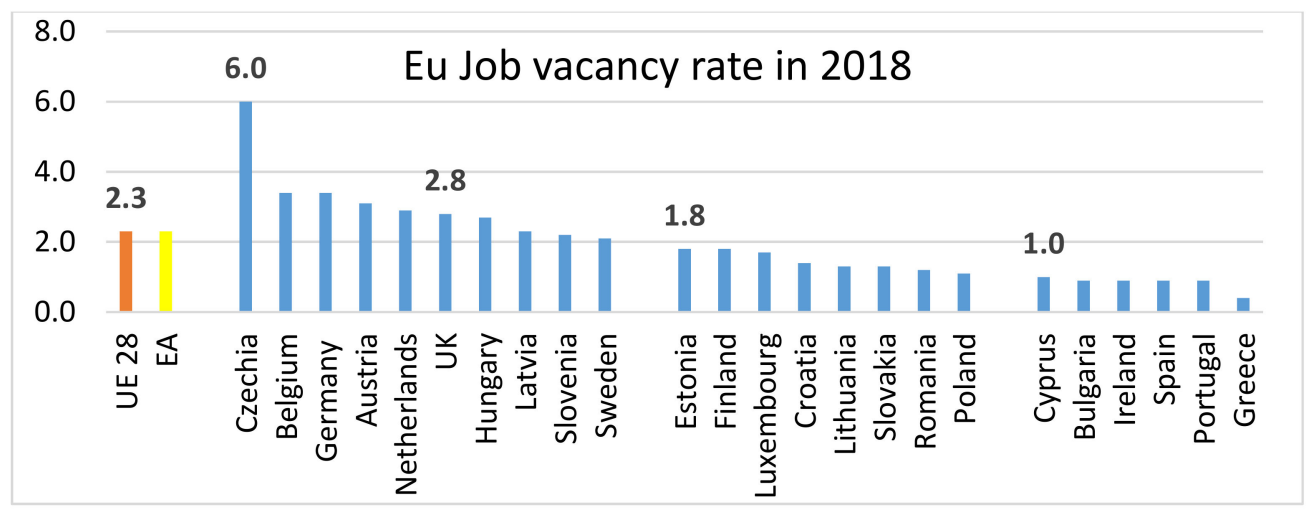

Figure 1. European Union (EU) job vacancy rate.

At the end of 2018, only in Germany, there were more than 3.4 million job vacancies, with more than 2.8 million in the United Kingdom or 90,000 in Spain alone, where unemployment was $14.5 \%$ at the end of 2018, one of the largest in the EU.

A considerable amount of vacancies was also recorded in 2018 in the ICT sector, one of the best paying sectors of the European economy (with more than 150,000 vacant jobs, and in Germany alone more than 80,000 jobs).

\subsection{An Explorative Investigation in the Romanian Labour Market}

In light of the results of the analysis in the European system, this study is focused on the case of Romania. It is the country with the largest gross domestic product (GDP) growth in the European Union (7\% in 2017), has one of the lowest unemployment rates (less than $5 \%$ in December 2017), has one of the lowest guaranteed minimum wages in the EU (about 409 starting 1 January 2018), and has one of the highest IT sector gross added value evolutions (a 93\% increase in 2016 compared to 2010 as opposed to 25\% for EU 28 since 2010).

In the Romanian labor market, unemployment is on a downward trend, but here, we are entering the post-hoc ergo propter hoc trap, as we are unable to establish with certainty how much of this decrease is guaranteed to increase the guaranteed minimum wage.

In order to understand whether Romanian unemployment is of the Keynesian or neoclassical type, we will test, through two OLS-type simple regressions, the following relations:

(1) for Keynesian unemployment, meaning that GDP (Y) and its evolution is the dependent variable that takes into account the employed workforce (L);

(2) for neo-classical unemployment, meaning that the employed workforce (L) is considered the dependent variable and whether it is in concordance with the evolution of GDP (Y).

The data for the first trimester of 2007-the third quarter of 2017 were collected from EUROSTAT and were differentiated by first degree, and a logarithm was used starting from the date of Romania's accession to the European Union. Thus, in our opinion, we have covered a sufficiently long period in which there were numerous changes in the direction of an increase of the guaranteed minimum wage in Romania.

By applying the OLS-type model, we see in Table 2 that in the case of the first relationship has (1) a GDP coefficient of 0.077 , while employment is 3148 . So, the Romanian labor market has a Keynesian type of market, one that has insufficient jobs. 
Table 2. Ordinary Least Squares results for the Romanian labor market.

\begin{tabular}{|c|c|c|c|c|c|c|c|c|c|}
\hline \multicolumn{5}{|c|}{ Dependent Variable: DL_EMPLOYMENT } & \multicolumn{5}{|c|}{ Dependent Variable: DL_GDP } \\
\hline Variable & Coefficient & $\begin{array}{l}\text { Std. } \\
\text { Error }\end{array}$ & t-Statistic & Prob. & Variable & Coefficient & $\begin{array}{l}\text { Std. } \\
\text { Error }\end{array}$ & t-Statistic & Prob. \\
\hline $\mathrm{C}$ & -0.005 & 0.005 & -0.905 & 0.371 & $\mathrm{C}$ & 0.035 & 0.033 & 1.087 & 0.284 \\
\hline R-Squared & 0.241 & \multicolumn{2}{|c|}{ Mean dependent var } & -0.003 & R-squared & 0.241 & \multicolumn{2}{|c|}{$\begin{array}{l}\text { Mean dependent } \\
\text { variable }\end{array}$} & 0.028 \\
\hline $\begin{array}{c}\text { S.E. of } \\
\text { regression }\end{array}$ & 0.032 & \multicolumn{2}{|c|}{ Akaike info criterion } & -4.013 & $\mathrm{SE}$ of regression & 0.203 & \multicolumn{2}{|c|}{ Akaike info criterion } & -0.299 \\
\hline $\begin{array}{c}\text { Sum } \\
\text { Squared } \\
\text { Residual }\end{array}$ & 0.037 & \multicolumn{2}{|c|}{ Schwarz criterion } & -3.928 & $\begin{array}{l}\text { Sum squared } \\
\text { residual }\end{array}$ & 1.529 & \multicolumn{2}{|c|}{ Schwarz criterion } & -0.213 \\
\hline F-statistic & 11.775 & \multicolumn{2}{|c|}{$\begin{array}{c}\text { Durbin-Watson } \\
\text { statistic }\end{array}$} & 2.183 & F-statistic & 11.775 & \multicolumn{2}{|c|}{$\begin{array}{l}\text { Durbin-Watson } \\
\text { statistic }\end{array}$} & 2.619 \\
\hline $\begin{array}{c}\text { Prob } \\
\text { (F-statistic) }\end{array}$ & & \multicolumn{2}{|c|}{0.001} & & Prob (F-statistic) & & \multicolumn{2}{|c|}{0.001} & \\
\hline
\end{tabular}

Source: own processing. SD—standard deviation; SE—-standard error.

Our study, unfortunately, only tells half of the story of the Romanian economy, because a territorial analysis led us to the conclusion that both types of unemployment are present in the Romanian economy. Starting from the fact that at the level of the national economy, in the fourth quarter of 2017 there were 54,663 job vacancies in the economy, and that in December 2017 in Romania, there were over 350,000 unemployed persons. In addition, there are counties where unemployment rates range between 1.07\% in Bucharest and the Western part of Romania, while the eastern counties have unemployment of more than $10 \%$. Romania, just like many countries in the EU, has disparity issues at a territorial level, where the two types of unemployment coexist in the Romanian economy.

We consider that in the West, North-West, and Centre regions, as well as Bucharest, a neoclassical type of unemployment is manifested, where the potential employees (in a very small number) have the opportunity to work but the salary is unsatisfactory. The South-West, South, South-East, and North-East regions show a Keynesian type of unemployment, with unemployed people unable to get employed because of a lack of jobs. This fact leads to the need to adopt differentiated policies and programs at a regional level. We believe that there is a need for a guaranteed minimum wage in Romania in order to increase employment and to decrease the risk of social exclusion due to unemployment and poverty.

Labor productivity in Romania is on an upward trend, reaching $65.2 \%$ of EU 28 productivity in 2017, while the average net salary in the economy was 2933 Lei (about 615 Euros) in February 2019. Considering that the average net salary in the EU 28 is 1520 Euros per month, the average salary in Romania is at $40.5 \%$ compared with the average salary in the EU 28 , and by putting it in relation with a productivity level of $65.2 \%$ of the European average, it is concluded that Romania has a high competitiveness compared with the EU 28 countries, being an attractive destination for foreign direct investment. The argument of a low wage level is not the only one determining the attractiveness of a country for foreign direct investments, as it also depends on the facilities offered to investors, the stability of tax legislation, and the business climate in that country. Unfortunately, during 2018, Romania was not a predictable business environment because of the multitude of changes in tax and labor legislation.

For economic development and an efficient labor market, foreign direct investments need to be stimulated. During the implementation of the catching up policy, economic competitiveness must be preserved, the correlation between raising the guaranteed minimum wage and increasing productivity being a must have. In the case of Romania, productivity is on an upward trend, with the possibility of 
raising the guaranteed minimum wage, not in a populist manner that falls within a political-electoral cycle, but rather considering a medium-term vision.

As we have shown above, Romania has one of the highest IT sector gross added value evolutions, thus having a competitive advantage. Also, an advantage of the Romanian economy is that low workforce costs ensure an increased competitiveness, which determine a high level of attractiveness for foreign direct investments, given that labor productivity is higher than the wage level $(65.2 \%$ compared to $40.5 \%$ ), thus making the relationship between wage growth and labor productivity extremely important.

In our opinion, maintaining the level of minimum wage could have been a stimulus of employment in Romania, and also for increasing the foreign direct investments. However, the minimum wage is a political decision that is being grounded in the electoral process, being announced as a social measure for decreasing social exclusion. The choice between wage led growth and capital led growth is being impaired by the elections and the social measures announced in the governance program.

\section{Findings}

\subsection{The Impact of ICT Skills on Employment and SME's Sustainable Competitiveness}

As we have seen in the first part of this study, there is a clear mismatch between the demand of supply of jobs in the EU market, present also in the IT sector with more than 160,000 vacant jobs, and also in the mismatch of skills within the IT sector. As stated above, our hypothesis (H1) is that ICT personnel (and implicitly ICT jobs) have a positive effect on job creation.

Basic economics tells us that the elasticity of the labor supply is related to a guaranteed minimum wage, and wage is related to productivity and training [66], especially in the IT sector [67]. So, a possible explanation for this mismatch of skills is measured by the level of training that the employers in the IT sector are demanding. In this regard, our study considers that the skills mismatch was considered by the share of employees with tertiary education in the ITC sector in the total number of employees in the ITC sector. Therefore, by dividing the number of IT personnel with a tertiary education to the number of IT personnel with a tertiary education and non-tertiary education, we determined an index of ITC skills mismatch. The mismatch is given by the skills offered by the tertiary education as opposed to the skills demanded by the labor market.

We are trying to analyze these issues with a panel VAR model for EU 27 (except for Croatia, as a result of a lack of data) for the period between 2007 and 2015.

It is important to mention that unemployment is generating social exclusion [68] because of low incomes and the increase of poverty. Also, we believe that an increase in employment in the ICT sector will bring an increase in the gross added value, will have a positive impact on GDP because of the increase of productivity, will create an increase in the number of employed persons, and will have a negative impact on the social exclusion of the unemployed.

So, the variables we have taken into consideration for this case study are as follows: gross domestic product per capita at PPS (Purchasing Power Parity), gross added value in the IT sector, number of IT personnel with tertiary education, number of IT personnel with tertiary education and non-tertiary education, number of persons employed, and risk of social exclusion of the unemployed.

The model proposed in order to make our research is as follows:

$$
\begin{gathered}
\operatorname{GDP}_{1, \mathbf{t}}=\boldsymbol{\alpha}_{2}+\Delta \sum_{\mathbf{j}=1}^{\mathbf{j}} \boldsymbol{\beta}_{1, \mathbf{j}} \operatorname{GDP}_{1, \mathbf{t}-\mathbf{j}}+\Delta \sum_{\mathbf{j}=1}^{\mathbf{j}} \boldsymbol{\delta}_{1, \mathbf{j}} \operatorname{GAV}_{1, \mathbf{t}-\mathbf{j}}+\Delta \sum_{\mathbf{k}=1}^{\mathbf{k}} \varepsilon_{1, \mathbf{j}} \mathbf{I T h i g h}_{1, \mathbf{t}-\mathbf{j}}+\Delta \sum_{\mathbf{k}=1}^{\mathbf{k}} \mathbf{\epsilon}_{1, \mathbf{j}} \text { ITtotal }_{1, \mathbf{t}-\mathbf{j}} \\
+\Delta \sum_{\mathbf{k}=1}^{\mathbf{k}} \boldsymbol{\theta}_{1, \mathbf{j}} \text { Exclusion }_{1, \mathbf{t}-\mathbf{j}}+\Delta \sum_{\mathbf{k}=1}^{\mathbf{k}} \boldsymbol{\theta}_{1, \mathbf{j}} \text { Employment }_{1, \mathbf{t}-\mathbf{j}}+\mathbf{u} 1_{\mathbf{t}}
\end{gathered}
$$

where:

GDP = gross domestic product per capita at PPS

$\mathrm{GAV}=$ gross added value in IT sector 
IThigh $=$ number of IT personnel with tertiary education

ITtotal $=$ number of IT personnel with tertiary education and non-tertiary education

Employment $=$ number of persons employed

Exclusion $=$ risk of social exclusion of the unemployed

ITC skill mismatch = number of IT personnel with tertiary education/number of IT personnel with a tertiary education and non-tertiary education

$$
\begin{aligned}
& \operatorname{GAV}_{1, \mathbf{t}}=\alpha_{2}+\Delta \sum_{\mathbf{j}=1}^{\mathbf{j}} \boldsymbol{\beta}_{1, \mathbf{j}} \operatorname{GDP}_{1, \mathbf{t}-\mathbf{j}}+\Delta \sum_{\mathbf{j}=1}^{\mathbf{j}} \boldsymbol{\delta}_{1, \mathbf{j}} \mathrm{GAV}_{1, \mathbf{t}-\mathbf{j}}+\Delta \sum_{\mathbf{k}=1}^{\mathbf{k}} \boldsymbol{\varepsilon}_{1, \mathbf{j}} \operatorname{IThigh}_{1, \mathbf{t}-\mathbf{j}}+\Delta \sum_{\mathbf{k}=1}^{\mathbf{k}} \boldsymbol{\epsilon}_{1, \mathbf{j}} \mathbf{I T t o t a l}_{1, \mathbf{t}-\mathbf{j}} \\
& +\Delta \sum_{\mathbf{k}=1}^{\mathbf{k}} \boldsymbol{\theta}_{1, \mathbf{j}} \text { Exclusion }_{1, \mathbf{t}-\mathbf{j}}+\Delta \sum_{\mathbf{k}=1}^{\mathbf{k}} \boldsymbol{\theta}_{1, \mathbf{j}} \text { Employment }_{1, \mathbf{t}-\mathbf{j}}+\mathbf{u} 1_{\mathbf{t}} \\
& \text { IThigh }_{1, \mathbf{t}}=\boldsymbol{\alpha}_{2}+\Delta \sum_{\mathbf{j}=1}^{\mathbf{j}} \boldsymbol{\beta}_{1, \mathbf{j}} \mathbf{G D P}_{1, \mathbf{t}-\mathbf{j}}+\Delta \sum_{\mathbf{j}=1}^{\mathbf{j}} \boldsymbol{\delta}_{1, \mathbf{j}} \mathbf{G A V}_{1, \mathbf{t}-\mathbf{j}}+\Delta \sum_{\mathbf{k}=1}^{\mathbf{k}} \varepsilon_{1, \mathbf{j}} \mathbf{I T h i g h}_{1, \mathbf{t}-\mathbf{j}}+\Delta \sum_{\mathbf{k}=1}^{\mathbf{k}} \mathbf{\epsilon}_{1, \mathbf{j}} \mathbf{I T t o t a l}_{1, \mathbf{t}-\mathbf{j}} \\
& +\Delta \sum_{\mathbf{k}=1}^{\mathbf{k}} \boldsymbol{\theta}_{1, \mathbf{j}} \text { Exclusion }_{1, \mathbf{t}-\mathbf{j}}+\Delta \sum_{\mathbf{k}=1}^{\mathbf{k}} \boldsymbol{\theta}_{1, \mathbf{j}} \text { Employment }_{1, \mathbf{t}-\mathbf{j}}+\mathbf{u} 1_{\mathbf{t}} \\
& \text { Exclusion }_{1, \mathbf{t}}=\boldsymbol{\alpha}_{2}+\Delta \sum_{\mathbf{j}=1}^{\mathbf{j}} \boldsymbol{\beta}_{1, \mathbf{j}} \operatorname{GDP}_{1, \mathbf{t}-\mathbf{j}}+\Delta \sum_{\mathbf{j}=1}^{\mathbf{j}} \boldsymbol{\delta}_{1, \mathbf{j}} \mathrm{GAV}_{1, \mathbf{t}-\mathbf{j}}+\Delta \sum_{\mathbf{k}=1}^{\mathbf{k}} \varepsilon_{1, \mathbf{j}} \operatorname{IThigh}_{1, \mathbf{t}-\mathbf{j}}+\Delta \sum_{\mathbf{k}=1}^{\mathbf{k}} \boldsymbol{\epsilon}_{1, \mathbf{j}} \operatorname{ITtotal}_{1, \mathbf{t}-\mathbf{j}} \\
& +\Delta \sum_{\mathbf{k}=1}^{\mathbf{k}} \boldsymbol{\theta}_{1, \mathbf{j}} \text { Exclusion }_{1, \mathbf{t}-\mathbf{j}}+\Delta \sum_{\mathbf{k}=1}^{\mathbf{k}} \boldsymbol{\theta}_{1, \mathbf{j}} \text { Employment }_{1, \mathbf{t}-\mathbf{j}}+\mathbf{u} 1_{\mathbf{t}} \\
& \text { Employment }_{1, \mathbf{t}}=\boldsymbol{\alpha}_{2}+\Delta \sum_{\mathbf{j}=1}^{\mathbf{j}} \boldsymbol{\beta}_{1, \mathbf{j}} \mathrm{GDP}_{1, \mathbf{t}-\mathbf{j}}+\Delta \sum_{\mathbf{j}=1}^{\mathbf{j}} \boldsymbol{\delta}_{1, \mathbf{j}} \mathrm{GAV}_{1, \mathbf{t}-\mathbf{j}}+\Delta \sum_{\mathbf{k}=1}^{\mathbf{k}} \varepsilon_{1, \mathbf{j}} \operatorname{IThigh}_{1, \mathbf{t}-\mathbf{j}}+\Delta \sum_{\mathbf{k}=1}^{\mathbf{k}} \boldsymbol{\epsilon}_{1, \mathbf{j}} \operatorname{ITtotal}_{1, \mathbf{t}-\mathbf{j}} \\
& +\Delta \sum_{\mathbf{k}=1}^{\mathbf{k}} \boldsymbol{\theta}_{1, \mathbf{j}} \text { Exclusion }_{1, \mathbf{t}-\mathbf{j}}+\Delta \sum_{\mathbf{k}=1}^{\mathbf{k}} \boldsymbol{\theta}_{1, \mathbf{j}} \text { Employment }_{1, \mathbf{t}-\mathbf{j}}+\mathbf{u} 1_{\mathbf{t}}
\end{aligned}
$$

After we estimated the VAR, we checked whether our model satisfied all of the necessary VAR tests. Thus, the VAR satisfies the stability condition, as shown in Table 3. It is ensured, in this way, the essential condition for VAR stability. If this test were not passed, it could not go further with the VAR methodology.

Table 3. VAR satisfies the stability condition.

\begin{tabular}{cc}
\hline Root & Modulus \\
\hline 0.999497 & 0.999497 \\
$0.330901-0.401447 \mathrm{i}$ & 0.520246 \\
$0.330901+0.401447 \mathrm{i}$ & 0.520246 \\
$-0.220393-0.055168 \mathrm{i}$ & 0.227193 \\
$-0.220393+0.055168 \mathrm{i}$ & 0.227193 \\
0.072755 & 0.072755
\end{tabular}

No root lies outside the unit circle. VAR satisfies the stability condition. Source: own processing.

The number of lags is chosen from one, as apparent from Table 4 . Thus, a change with a unit of the independent variable will have an effect on the dependent variable within one year.

Also, VAR satisfies the condition of heteroscedasticity, according to Table 5. Similar to the autocorrelation test mentioned above, this condition is respected, being an essential condition in validating the VAR methodology. 
Table 4. Selection of number of lags.

\begin{tabular}{ccccccc}
\hline Lag & LogL & LR & FPE & AIC & SC & HQ \\
\hline 0 & 86.80363 & NA & $2.02 \times 10^{-9}$ & -2.992727 & -2.771729 & -2.907497 \\
1 & 268.4650 & $316.2254 *$ & $9.25 \times 10^{-12} *$ & -8.387593 & $-6.840605^{*}$ & $-7.790981^{*}$ \\
2 & 284.2230 & 23.92887 & $2.06 \times 10^{-11}$ & -7.637891 & -4.764914 & -6.529896 \\
3 & 306.6568 & 29.08072 & $3.87 \times 10^{-11}$ & -7.135435 & -2.936469 & -5.516059 \\
4 & 349.5572 & 46.07829 & $3.93 \times 10^{-11}$ & -7.391008 & -1.866053 & -5.260250 \\
5 & 397.1344 & 40.52874 & $4.20 \times 10^{-11}$ & -7.819794 & -0.968849 & -5.177653 \\
6 & 451.9835 & 34.53459 & $5.09 \times 10^{-11}$ & $-8.517908^{*}$ & -0.340973 & -5.364385 \\
\hline
\end{tabular}

* represents the best Lag selection order; NA—not applicable; LogL: Log likelihood; LR: sequential modified LR test statistic (each test at 5\% level); FPE: Final prediction error; AIC: Akaike information criterion; SC: Schwarz information criterion; HQ: Hannan-Quinn information criterion; source: own processing.

Table 5. Heteroscedasticity test.

\begin{tabular}{ccc}
\hline \multicolumn{3}{c}{ Joint Test } \\
\hline Chi-square & df & Prob. \\
\hline 944.7042 & 567 & 0.0000 \\
\hline \multicolumn{3}{c}{ Source: own processing. }
\end{tabular}

The VAR satisfies the autocorrelation condition, as shown in Table 6. This condition is respected by using the Lagrange Multiplier (LM) autocorrelation test, an essential condition for validating the VAR methodology.

Table 6. Autocorrelation conditions of the LM test.

\begin{tabular}{ccc}
\hline Lags & LM-Stat & Prob \\
\hline 1 & 62.00175 & 0.0045 \\
\hline \multicolumn{3}{c}{ Source: own processing. }
\end{tabular}

Following the verification of the VAR stability conditions and the tests ensuring data accuracy, we performed the impulse functions to observe the impact of the ICT personnel, both with tertiary education and the total number of ICT workers on employment, social exclusion, gross added value within the ICT sector, and GDP per capita.

As we can see from the figures below (Figures 2-4), the ICT personnel have a positive impact on employment, gross added value, and GDP per capita for the whole six-year period that we considered.

Thus, our hypotheses- $\mathrm{H} 1$ and H2.1-were validated, and in these conditions, we can state that ICT personnel and skills have a positive effect on employment and growth.

Also, very importantly, the ICT personnel have a negative impact on social exclusion, thus an increase in the number on ICT personnel influences, in a negative manner, the social exclusion of the unemployed. The fact that ICT personnel have a negative impact on social exclusion is important, as the gross added value produced by the IT sector is decreasing the risk of poverty.

Also, Hypothesis 2.2 was validated, and we can state that ICT personnel and skill have a negative effect on social exclusion. 
Accumulated Response to Cholesky One S.D. Innovations \pm 2 S.E. Accumulated Response of DL_EMPLOYMENT to DL_ITHIGH

Accumulated Response of DL_EXCLUSION to DL_ITHIGH
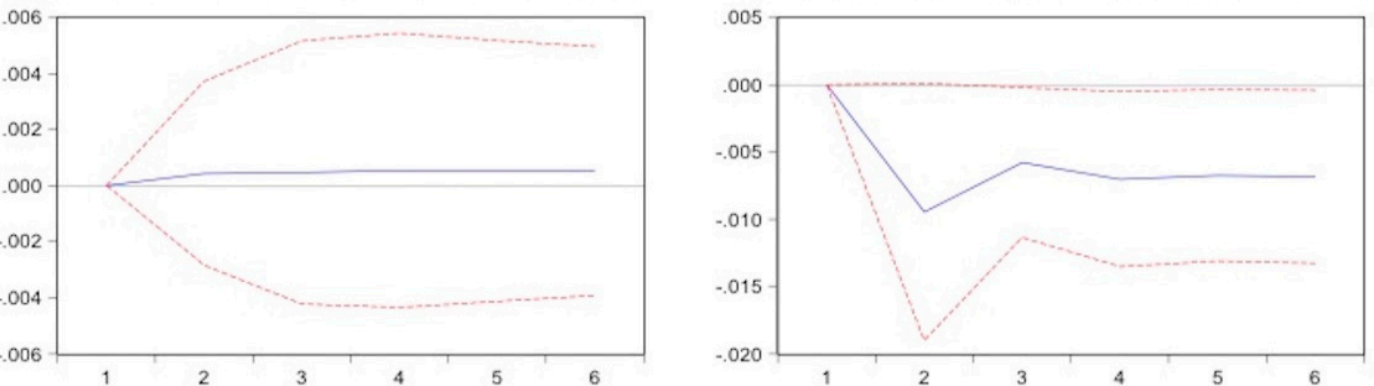

Accumulated Response of DL_GAV to DL_ITHIGH

Accumulated Response of DL_GDP to DL_ITHIGH
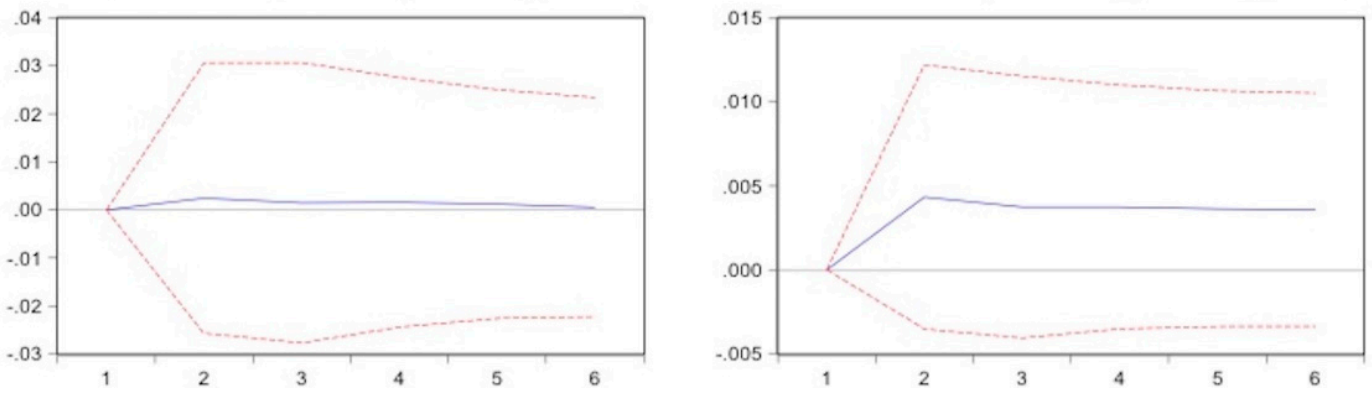

Figure 2. Impact of information technology (IT) personnel with tertiary education on employment, social exclusion, gross added value, and gross domestic product (GDP) per capita. SD—standard deviation; SE-standard error.

Accumulated Response to Cholesky One S.D. Innovations \pm 2 S.E.

Accumulated Response of DL_EMPLOYMENT to DL_ITTOTAL

Accumulated Response of DL_EXCLUSION to DL_ITTOTAL
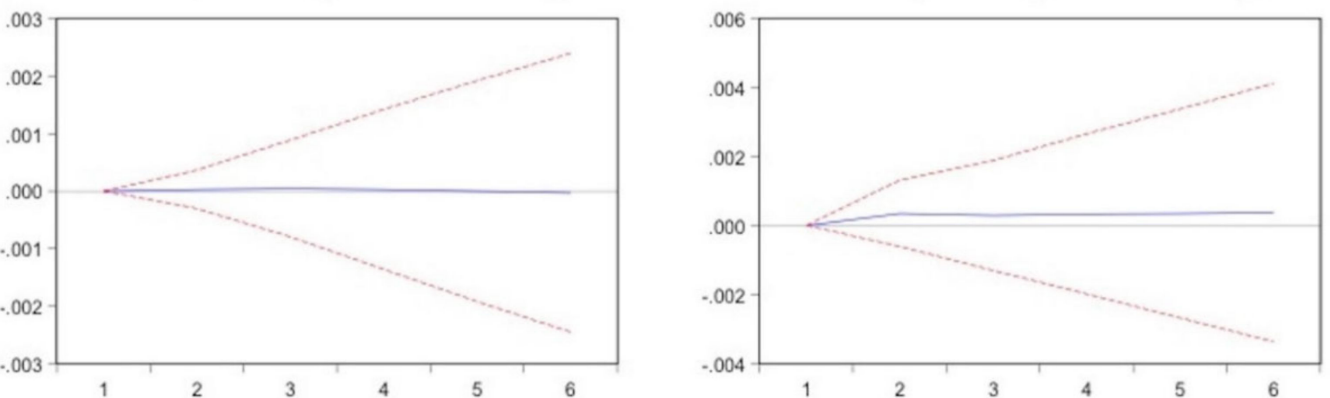

Accumulated Response of DL_GAV to DL_ITTOTAL

Accumulated Response of DL_GDP to DL_ITTOTAL
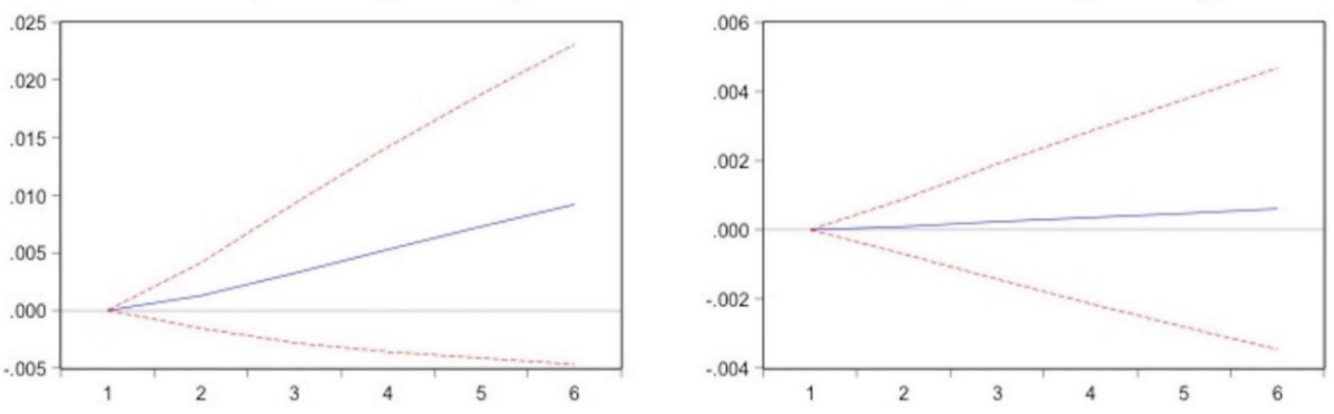

Figure 3. Impact of total IT personnel (tertiary education and no tertiary education) on employment, social exclusion, gross added value, and GDP per capita. 
Accumulated Response of DL_EXCLUSION to Cholesky One S.D. DL_EMPLOYMENT Innovation

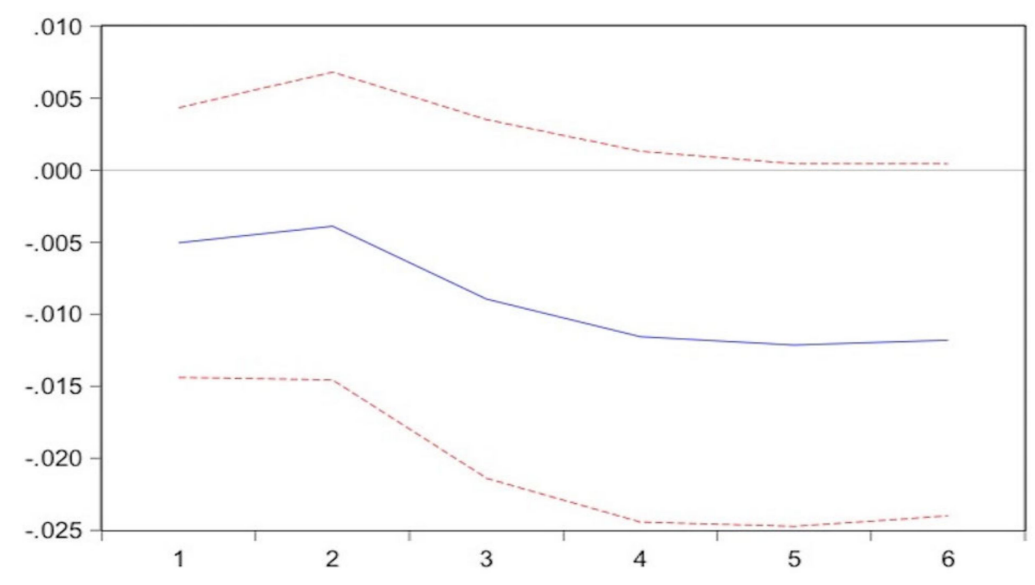

Figure 4. Impact of employment on social exclusion.

\subsection{The Impact of Guaranteed Minimum Wage on Employment and SME's Sustainable Competitiveness}

Also, we have identified that an increase in employment is reducing the social exclusion phenomena in our case study, thus being very important for public policies to increase employment by stimulating the change of perception of the unemployed. In accordance with our hypotheses- $\mathrm{H} 2.1$ and H 2.2-we have seen that ICT personnel and skills have a positive impact on employment and a negative impact on social exclusion. However, in the case of our third hypothesis (H3), a useful tool is the evolution and the implications of the minimum wage on employment. Our hypothesis, as stated above, is that the increase of the minimum wage is stimulating employment and job creation.

The pros and cons for the guaranteed minimum wage have been well documented in a multitude of studies staring from 1938, since the "The Fair Labor Standards Act" [69]. Brown et al. (1982) [70] has stated that the guaranteed minimum wage could cause job losses, and was not well targeted to the persons that it was supposed to help.

Although the guaranteed minimum wage is seen as a tool for redistributive goals, the necessity for a minimum wage is still a very debatable subject, and there is no consensus on the employment effects of the guaranteed minimum wage [71].

Still, large numbers of researchers have come up to the conclusion that the employment effect is elusive, as the labor market has large deviations from perfect competition, unlike the products market [72].

An interesting case is the case of Romania, which has applied a wage led growth strategy starting January 2017, increasing the guaranteed minimum wage several times during the last ten years and addressing the issue by increasing still, staring from January 2019 and January 2020. This evolution can be observed in Figure 5. If we analyze the basic facts, we can see that during the last years, the total number of employed persons grew steadily at the same pace as the guaranteed minimum wage.

We have to keep in mind that Romania has the largest emigration process of any EU 28 country (almost 3.6 million in 2017, according to the United Nations), and has a falling birth rate and an increasing ageing population. So, taking into considerations that the vast majority of emigrants from Romania can be considered as part of the active population, able to work, and in spite of emigration process, the country has encountered an increase in employment, we can state that the increase in the guaranteed minimum wage has had an impact on the Romanian labor market, increasing employment $[73,74]$. During the last 10 years, the Romanian economy has managed to create an additional 800,000 new jobs, but measuring the impact of the increase of guaranteed minimum wage on these new jobs is not that simple.

In this regard, we have analyzed the data form EUROSTAT and the Romanian National Statics Institute, and drew a few conclusions. 


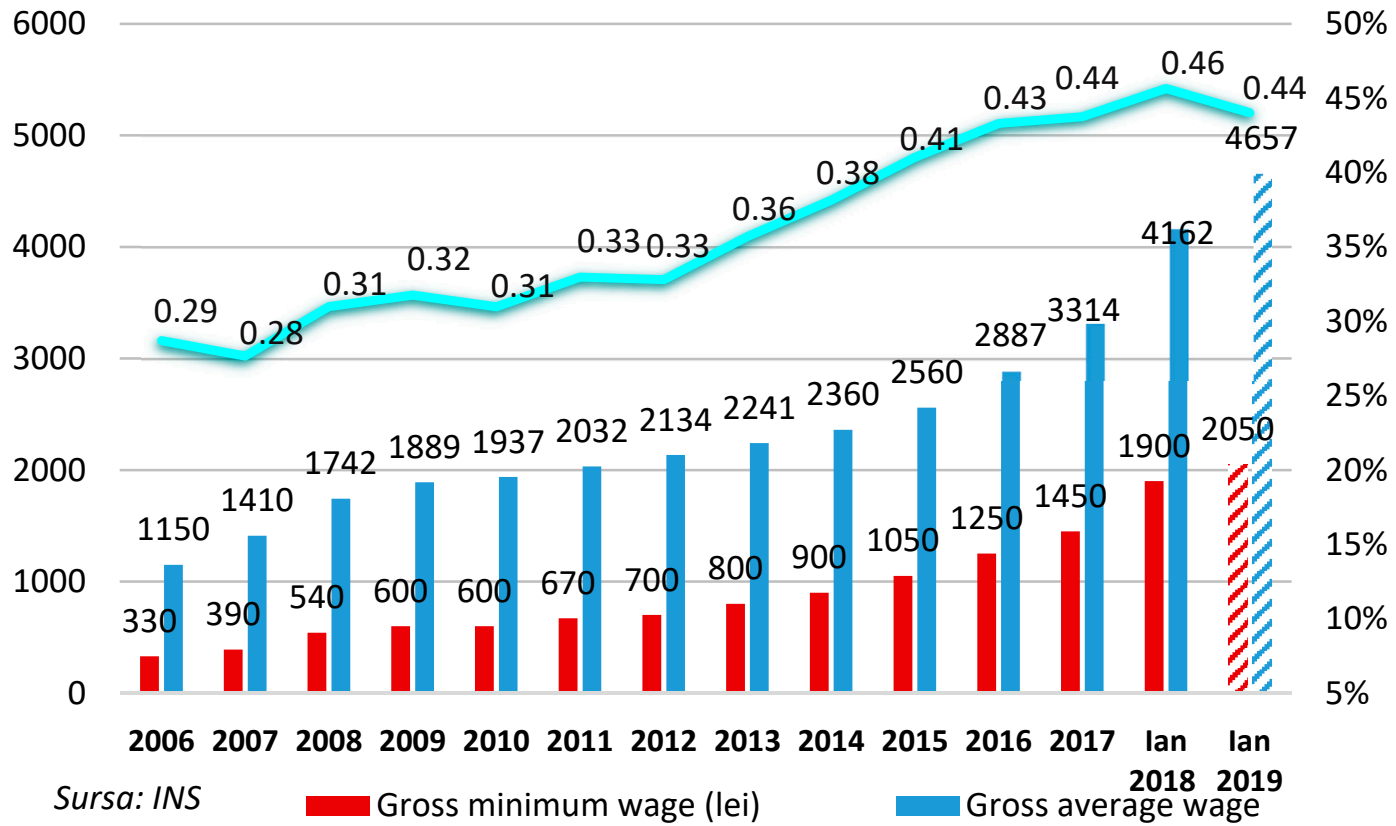

Figure 5. The evolution of the minimum wage in Romania 2006-2019.

As we can see in Figure 6, by increasing the guaranteed minimum wage, the Romanian authorities have increased the share of personnel with a guaranteed minimum wage in the total number of employees. So, if in 2010 there were 334 thousand persons employed with a guaranteed minimum wage out of a total of 4.1 million employees (8.2\%), in 2017 there were 1.37 million persons with a guaranteed minimum wage out of a total of 4.9 million employees $(28.3 \%)$.

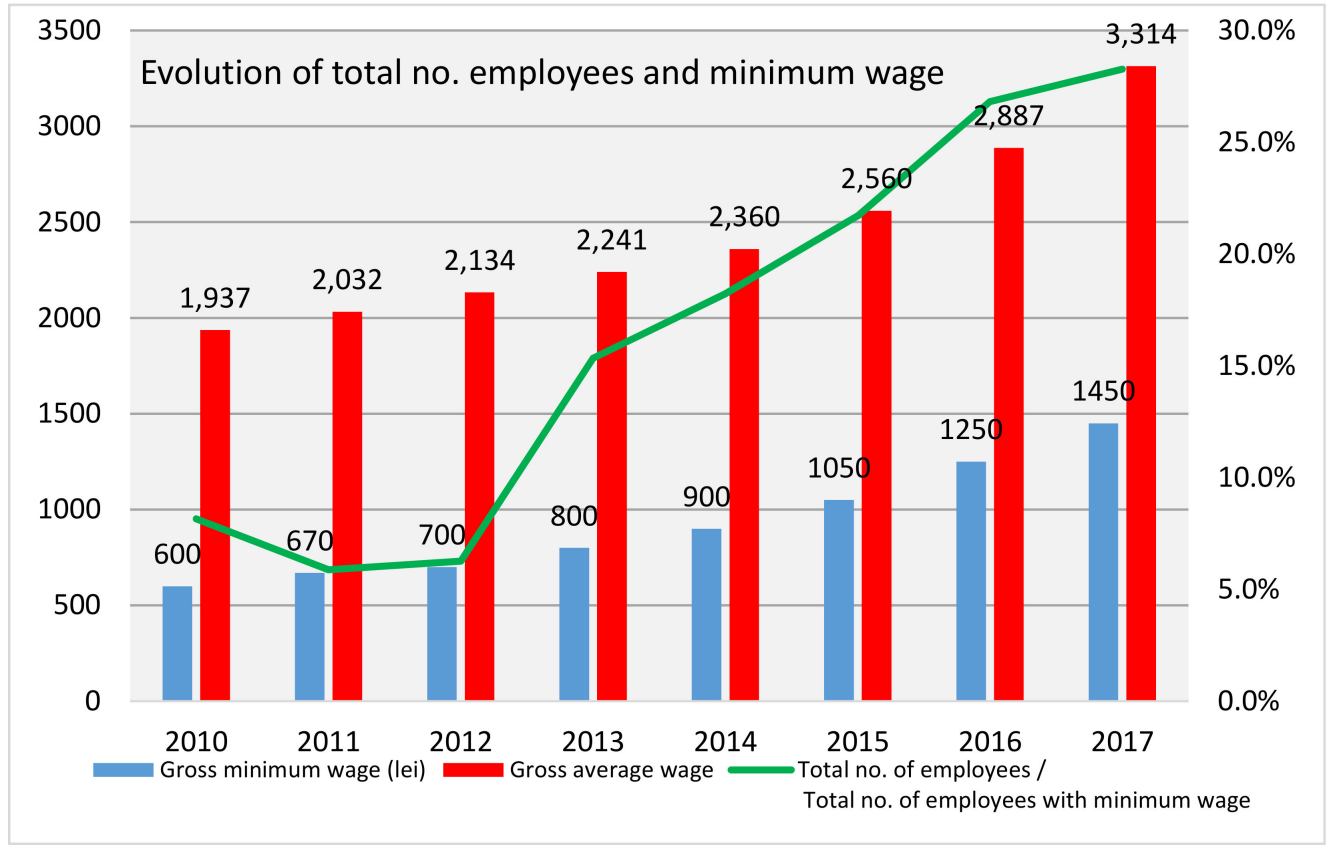

Figure 6. Evolution of the total number of employees and minimum wage.

In our opinion, we can state that the guaranteed minimum wage did had a positive effect on employment, by increasing of the number of new jobs by more than 800,000 in just 10 years, but the consequences were that the total number of guaranteed minimum wage persons increased in the total number of employees, from $8 \%$ to $28 \%$. 
So, in regard to our third hypothesis (H3), we can state that the minimum wage has had a positive effect on job creation and employment. Nevertheless, the Romanian labor market has focused on the creations of low added value jobs and not jobs with a higher added value, such as the ICT sector.

Another consequence of this wage led growth is that, during the years, the share of guaranteed minimum wage in the average wage has increased, causing a lower wage dispersion and a slower increase of productivity compared to the wages. So, in Figure 7, we can clearly see a decoupling of wages from productivity

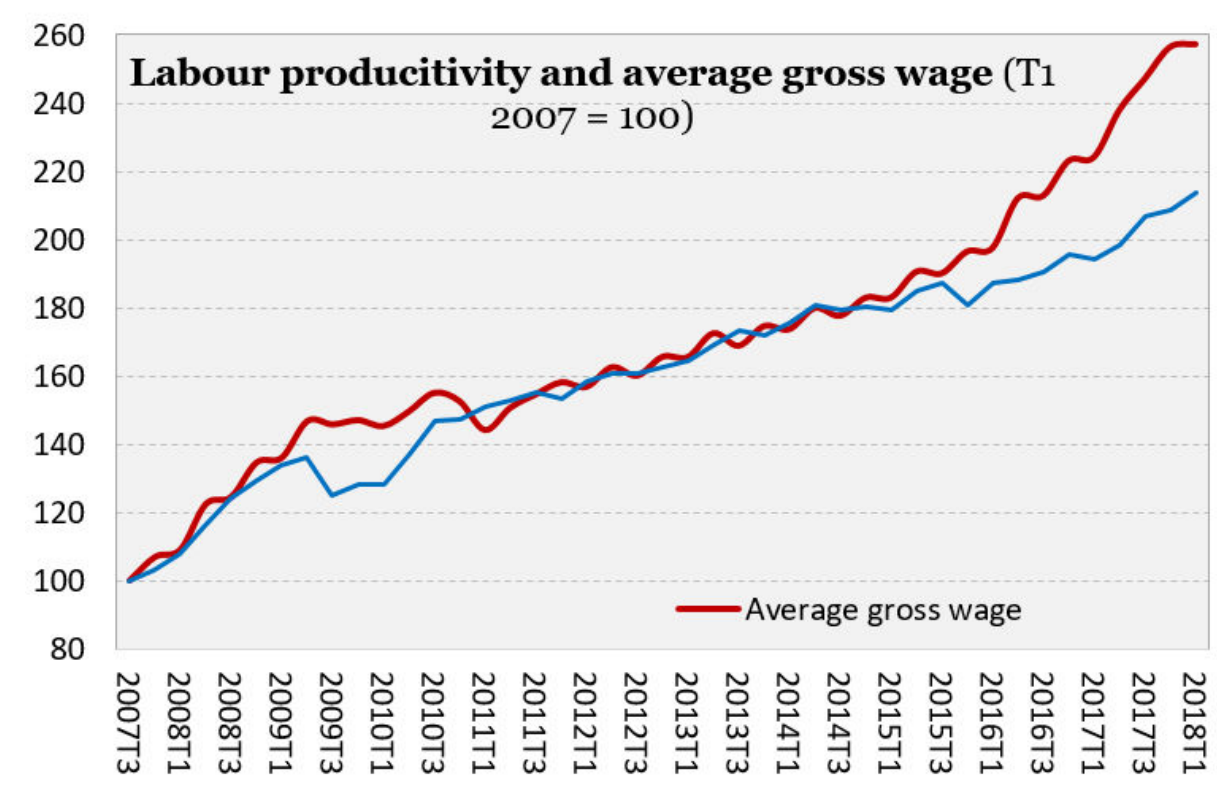

Figure 7. The evolution of labor productivity and wages in Romania 2007-2018.

We conclude that in Romania, the wage led growth policy has topped-out, reaching its full potential of growth for the time being. In this approach, the wages cannot increase anymore, and the most exposed to a risk of unemployment, in our opinion, will be the persons with the lowest ICT skills and the guaranteed minimum wage.

\section{Conclusions}

We have examined the impact of ICT skills mismatch and guaranteed minimum wages on SME's sustainable competitiveness in European countries in the context of Keynesian and Neoliberal markets. The empirical analysis was based on two approaches for our case studies, namely: one at a European level, considering the EU labor market, and a second targeting a specific country, Romania, which has one of highest ICT sector shares and GDP, and is also a country that has implemented a wage led growth.

By analyzing the European labor market for a time frame of 16 years (2000-2016), we have determined the European labor market to be of Keynesian designation, which is very important, as the $\mathrm{EU}$, as a whole, has insufficient jobs and high unemployment.

Despite the fact that the EU has large regional disparities, and by analyzing the case of Romania, for the same time span, we have come to the same conclusion, that is, the Romanian labor market is Keynesian with insufficient jobs.

For the second part of our analysis, we tried to see if the ICT skills and the minimizing of the skills mismatch can increase employment, create jobs, increase GDP per capita, and thus decrease social exclusion. We have analyzed quarterly data for the period of 2007-2015 for every EU country (except Croatia), and found out that the ICT skills can increase employment and decrease social exclusion, which confirms the literature review regarding innovation and job creation. 
Therefore, Hypotheses $\mathrm{H} 1$ and H2.1 have proven that ICT personnel and skills have a positive effect on employment and growth. Also, our results show that, as we have anticipated, an educated workforce in the ICT sector has a larger impact on the variables selected for the VAR model, increasing employment and decreasing social exclusion.

We have seen that there is a clear difference between the impacts of the tertiary education ICT personnel and the non-tertiary education personnel on GDP, gross added value, employment, and social exclusion. Therefore, Hypothesis H 2.2 was verified, showing that ICT skills and ICT personnel have a negative effect on social exclusion.

However, although the European labor market is a Keynesian type of labor market, with insufficient jobs for the unemployed workforce, there are still a large number of vacant jobs in the European economy, as we have shown above. The same principle applies to the ICT labor market, where there are still a large number of vacant jobs, a clear sign of certain mismatch in the demand and offer of skills between the unemployed and the employers. A possible explanation could be the level of training-tertiary or non-tertiary education.

For the third topic that we approached, regarding guaranteed minimum wage and job creation, we discussed the Romanian economy and labor market that recently started a strong wage led growth approach. We have seen that during the last decade, the total new jobs created increased by nearly a quarter, but the total number of guaranteed minimum wage jobs increased from $8 \%$ out of the total jobs to $28 \%$ of the total jobs.

So, the increase in guaranteed minimum wage is creating jobs, but it creates low wage jobs and not necessarily an increase in wellbeing. Therefore, we consider that our third hypothesis (H3) was verified, but the effects of the minimum wage are unsatisfactory, as the creation employment has grown by low paying jobs, with little effect on wellbeing.

All policy makers have to keep in mind that increasing employment within the economy is of the upmost importance, and also, a clear orientation of any responsible policy maker has to be the reduction of social exclusion and the combat of poverty. In order to achieve these objectives, the policy makers can implement a public policy in order to increase employment through an increase of the guaranteed minimum wage.

However, an increase in the minimum wage, taking into consideration the increase in productivity, in our opinion, is a healthy approach for stimulating economic growth and increasing SME competitiveness. However, a minimum wage that is set arbitrary by the government is going to develop into an unsustainable public policy, with negative implications that will lead to unemployment and inflation.

As we have seen in the VAR model and its results, an increase in employment has a negative impact on social exclusion, so the policy makers have to set certain incentives for reducing unemployment-a guaranteed minimum wage could be an instrument in this approach, with the Romanian case being an interesting approach.

Also, we have seen that an increase in ICT personnel skills and training will determine an increase in the gross added value of the ICT sector in the GDP, together with an increase of employment combined with a decrease of social exclusion. A guaranteed minimum wage approach has to keep in mind that the level of minimum wage has to be linked to productivity and economic performance in order to keep an economy competitive and sustainable in the long run.

\section{Research Implication}

This research puts forward evidence about the scientific progress on the specific topic of streaming research processes that drive efficient and effective systems to manage a higher organizational labor market so as to improve performance and economic returns.

In particular, the technological implications for the workforce in terms of employment skills mismatch can be opportunities in times of disruptive change, in which economies have to be more resilient. This study can be useful for corporate management, public, no-profit and private companies, 
human resource management, customers, and citizens to improve the decision-making process in labor market.

The emerging economies also face a number of challenges. Rapid advances in automation and the use of robots, together with some re-shoring of jobs in advanced economies, may limit the jobs potential of an expanding manufacturing sector. This may make it harder to escape the middle-income trap, and to ensure a more even sharing of increased prosperity. It could also make it harder to generate the job growth required to provide employment opportunities for the large number of young people entering the labor market each year in many of the emerging economies. Moreover, providing these large cohorts of young people with the right skills to find good jobs will also be a major challenge. Going forward, some of these challenges include the design and implementation of policies which will do the following:

(1) Prepare young people for the jobs of the future, by ensuring that they are equipped with the right type of skills to successfully navigate through an ever-changing, technology-rich work environment, and give all workers the opportunity to continuously maintain their skills, up skill and/or riskily throughout their working lives.

(2) Design labor market institutions (e.g., guaranteed minimum wage, employment protection, and health and safety regulations) that encourage employers to seize the opportunities offered by technological change and globalization, while making sure that the risks are not borne disproportionately by workers in the form of low pay, precariousness, and poor working conditions.

(3) Re-think social security systems to minimize the chances of people slipping through the holes by (i) tailoring or adapting them to the new forms of employment, or (ii) decoupling them entirely from people's work status and history.

(4) Strengthen activation frameworks to mitigate some of the inevitable adjustment costs of moving towards more globalized and technologically advanced economies by helping those workers who have been displaced by changing skills needs into a new job quickly.

(5) Promote new forms of social dialogue that allow for tailored solutions to new challenges to emerge at the firm-level, while strengthening the voice of those workers who are increasingly working independently and separated by distance, language, and legal context.

Author Contributions: All the authors contributed in an equal way to the conception and drafting of the paper.

Funding: This research received no external funding.

Conflicts of Interest: The authors declare no conflict of interest.

\section{References}

1. Scholarios, D.; Van der Heijden, B.I.; Van der Schoot, E.; Bozionelos, N.; Epitropaki, O.; Jedrzejowicz, P.; Knauth, P.; Marzec, I.; Mikkelsen, A.; Van der Heijde, C.M. Employability and the psychological contract in European ICT sector SMEs. Int. J. Hum. Resour. Manag. 2008, 19, 1035-1055. [CrossRef]

2. Gastaldi, L.; Corso, M. Smart healthcare digitalization: Using ICT to effectively balance exploration and exploitation within hospitals. Int. J. Eng. Bus. Manag. 2012, 4. [CrossRef]

3. Gobe, M. Emotional Branding: The New Paradigm for Connecting Brands to People; Skyhorse Publishing, Inc.: New York, NY, USA, 2001.

4. Gravili, G.; Benvenuto, M.; Avram, A.; Viola, C. The influence of the Digital Divide on Big Data generation within supply chain management. Int. J. Logist. Manag. 2008, 29, 592-628. [CrossRef]

5. Wilden, R.; Gudergan, S.; Lings, I. Employer branding: Strategic implications for staff recruitment. J. Mark. Manag. 2010, 26, 56-73. [CrossRef]

6. Lazear, E.P.; Oyer, P. Personnel Economics. In Handbook of Organisational Economics; Gibbons, R., Roberts, D.J., Eds.; Princeton University Press: Princeton, NJ, USA, 2009.

7. Handel, M.J. Skills mismatch in the labor market. Ann. Rev. Sociol. 2003, 29, 135-165. [CrossRef] 
8. Zulkifly, O.; Ishak, Y.; Abu Hassan, M.S. Inflasi pendidikan mengikut ketentuan dalam pasaran buruh Malaysia. J. Ekon. Malays. 2010, 44, 61-71.

9. Quintini, G. Over-Qualified or Under-Skilled. 2011. Available online: https://www.oecd-ilibrary.org/content/ paper/5kg58j9d7b6d-en (accessed on 18 March 2019).

10. Bennett, S.; Maton, K.; Kervin, L. The 'digital natives' debate: A critical review of the evidence. $B r$. J. Educ. Technol. 2008, 39, 775-786. [CrossRef]

11. McGuinness, S.; Pouliakas, K.; Redmond, P. How Useful is the Concept of Skills Mismatch? 2017. Available online: http://hdl.handle.net/10419/170770 (accessed on 18 March 2019).

12. Hagemejer, K. Review of approaches to assess the sustainability of social protection floors. In Social Protection Goals in East Asia; Taylor \& Francis Group: London, UK, 2018; Available online: https://www.taylorfrancis. com/books/e/9781351867788/chapters/10.4324\%2F9781315232348-2 (accessed on 18 March 2019).

13. Mortensen, D.T. Unemployment insurance and job search decisions. ILR Rev. 1977, 30, 505-517. [CrossRef]

14. Shavell, S.; Weiss, L. The optimal payment of unemployment insurance benefits over time. J. Polit. Econ. 1979, 87, 1347-1362. [CrossRef]

15. Carone, G.; Salomaki, A.; Immervoll, H.; Paturot, D. Indicators of Unemployment and Low-Wage Traps; OECD Social, Employment and Migration Working Paper No. 18; OECD: Paris, France, 2003.

16. Matković, T.; Caha, D. Patterns of welfare-to-employment transitions of Croatian Guaranteed Minimum Benefit recipients: A preliminary study. Pub. Sect. Econ. 2017, 41, 335-358. [CrossRef]

17. Hemerijck, A. The self-transformation of the European social model(s). Int. Polit. Ges. 2002, 4, 39-67.

18. Bargain, O.; Orsini, K. In-work policies in Europe: Killing two birds with one stone? Labour Econ. 2006, 13, 667-697. [CrossRef]

19. Card, D.; Krueger, A.B. Myth and Measurement: The New Economics of the Minimum Wage-Twentieth-Anniversary Edition; Princeton University Press: Princeton, NJ, USA, 2015.

20. Lloyd, C.; Payne, J. Licensed to skill? The impact of occupational regulation on fitness instructors. Eur. J. Ind. Relat. 2017. [CrossRef]

21. Freeman, R.B. Minimum Wages-Again! Int. J. Manpow. 1994, 15, 8-25. [CrossRef]

22. Kalleberg, A.L. The mismatched worker: When people don't fit their jobs. Acad. Manag. Perspect. 2008, 22, 24-40. [CrossRef]

23. Farooq, S. Mismatch between education and occupation: A case study of Pakistani graduates. Pak. Dev. Rev. 2011, 50, 531-552. [CrossRef]

24. Gravili, G.; Fait, M. Social Recruitment in HRM: A Theoretical Approach and Empirical Analysis; Emerald Group Publishing Limited: Bingley, UK, 2016.

25. Groot, W.; Van Den Brink, H.M. Overeducation in the labor market: A meta-analysis. Econ. Educ. Rev. 2000, 19, 149-158. [CrossRef]

26. Chambers, E.G.; Foulon, M.; Handfield-Jones, H.; Hankin, S.M.; Michaels, E.G. The war for talent. McKinsey Q. 1998, 44-57. Available online: http://www.executivesondemand.net/managementsourcing/images/stories/ artigos_pdf/gestao/The_war_for_talent.pdf (accessed on 18 March 2019).

27. McGuinness, S. Overeducation in the labour market. J. Econ. Surv. 2006, 20, 387-418. [CrossRef]

28. Rubb, S. Overeducation in the labor market: A comment and re-analysis of a meta-analysis. Econ. Educ. Rev. 2003, 22, 621-629. [CrossRef]

29. Sloane, P.J. Much ado About Nothing? What does the Overeducation Literature Really Tell us. In Overeducation in Europe; Edward Elgar Publishing: Cheltenham, UK, 2003.

30. Halaby, C.N. Overeducation and skill mismatch. Sociol. Educ. 1994, 67, 47-59. [CrossRef]

31. Desjardins, R.; Rubenson, K. An Analysis of Skill Mismatch Using Direct Measures of Skills; OECD Education Working Paper No. 63; OECD Publishing: Paris, France, 2011.

32. Verhaest, D.; Sellami, S.; Van der Velden, R. Differences in horizontal and vertical mismatches across countries and fields of study. Int. Labour Rev. 2017, 156, 1-23. [CrossRef]

33. Domadenik, P.; Farcnik, D.; Pastore, F. Horizontal Mismatch in the Labour Market of Graduates: The Role of Signaling. IZA Discussion Paper No. 7527. Available online: https://papers.ssrn.com/sol3/papers.cfm? abstract_id=2314822 (accessed on 18 March 2019).

34. Acemoglu, D.; Autor, D. Skills, Tasks and Technologies: Implications for Employment and Earnings. In Handbook of Labor Economics; Elsevier: Amsterdam, The Netherlands, 2011; Volume 4, pp. 1043-1171. 
35. Allen, J.; Van der Velden, R. Educational Mismatches versus Skill Mismatches: Effects on Wages, Job Satisfaction, and On-the-Job Search. Oxf. Econ. Pap. 2001, 53, 434-452. [CrossRef]

36. Heckman, J.J. Skill formation and the economics of investing in disadvantaged children. Science 2006, 312, 1900-1902. [CrossRef] [PubMed]

37. Jackson, D. An international profile of industry-relevant competencies and skill gaps in modern graduates. Int. J. Manag. Educ. 2010, 8, 29-58. [CrossRef]

38. Cappelli, P.H. Skill gaps, skill shortages, and skill mismatches: Evidence and arguments for the United States. ILR Rev. 2015, 68, 251-290. [CrossRef]

39. Foley, P.D.; Watts, H.D. Skills shortages and training a forgotten dimension in new technology. R D Manag. 1994, 24, 99-109.

40. Rosen, S. Measuring the obsolescence of knowledge. In Education, Income, and Human Behavior; Thomas Juster, F., Ed.; NBER: Cambridge, MA, USA, 1975; pp. 199-232.

41. Allen, J.; de Grip, A. Does skill obsolescence increase the risk of employment loss? Appl. Econ. 2012, 44, 3237-3245. [CrossRef]

42. Caroli, E.; Van Reenen, J. Skill-biased organizational change? Evidence from a panel of British and French establishments. Q. J. Econ. 2001, 116, 1449-1492. [CrossRef]

43. OECD. Enhancing the Competitiveness of SMES in the Global Economy: Strategies and Policies; OECD: Paris, France, 2013.

44. Piva, M.; Santarelli, E.; Vivarelli, M. The skill bias effect of technological and organisational change: Evidence and policy implications. Res. Policy 2005, 34, 141-157. [CrossRef]

45. Thoenig, M.; Verdier, T. A theory of defensive skill-biased innovation and globalization. Am. Econ. Rev. 2003, 93, 709-728. [CrossRef]

46. Cișmaș, L. Microeconomia Bunăstării; Editura Mirton: Timișoara, Romania, 2004; p. 279.

47. Ailenei, D.; Angelescu, C.; Cristescu, A.; Hrisanta, M. A Fuzzy Sets Model for Companies Behaviour of Absorption Minimum WageShocks: An Analysis of Inflationary Risks. IBIMA Publishing Journal of Economics Studies and Research. 2011. Available online: http://www.ibimapublishing.com/journals/JESR/ jesr.html (accessed on 18 March 2019).

48. Sutch, R. The Unexpected Long-Run Impact of the Minimum Wage: An Educational Cascade; No. w16355; National Bureau of Economic Research: Cambridge, UK, 2010.

49. Fox, L. Minimum Wage Trends: Understanding Past and Contemporary Research; Economic Policy Institute: Washington, DC, USA, 2006.

50. Semmel, B. Imperialism and Social Reform; George Allen \& Unwin Ltd. Anchor Books Doubleday \& Company, Inc.: Garden City, NY, USA, 1960.

51. Alesina, A.F.; Zeira, J. Technology and Labour Regulations; NBER Working Paper No. 12581; National Bureau of Economic Research: Cambridge, MA, USA, 2006.

52. Abbott, L.F. Statutory Minimum Wage Controls: A Critical Review of their Effects on Labour Markets, Employment, and Incomes, 2nd ed.; ISR Publications: Manchester, UK, 2000; ISBN 978-0-906321-22-5.

53. Rockwell, L.H., Jr. Wal-Mart Warms to the State. 2005. Available online: https://mises.org/library/wal-martwarms-state (accessed on 10 March 2019).

54. Partridge, M.D.; Partridge, J.S. Do minimum wage hikes reduce employment? State-level evidence from the low-wage retail sector. J. Labor Res. 1999, 20, 393-413. [CrossRef]

55. Wilson, M. Increasing the Mandated Minimum Wag: Who Pays the Price? The Heritage Foundation: Washington, DC, USA, 1998; Available online: https://www.heritage.org/budget-and-spending/report/increasing-themandated-minimum-wage-who-pays-the-price (accessed on 16 March 2019).

56. Meer, J.; West, J. Effects of the minimum wage on employment dynamics. J. Hum. Resour. 2016, 51, 500-522. [CrossRef]

57. Atkinson, R.D. Create Jobs by Expanding the RED Tax Credit; Information Technology and Innovation Foundation: Washington, DC, USA, 2010.

58. Klette, J.; Førre, S.E. Innovation and job creation in a smallopen economy-evidence from norwegian manufacturing plants 1982-92. Econ. Innov. New Technol. 1998, 5, 247-272. [CrossRef]

59. Linden, G.; Dedrick, J.; Kraemer, K.L. Innovation and job creation in a global economy: The case of Apple's iPod. J. Int. Commer. Econ. 2011, 3, 223-239. 
60. Kletzer, L.G. Imports, Exports, and Jobs: What Does Trade Mean for Employment and Job Loss? WE Upjohn Institute: Kalamazoo, MI, USA, 2002.

61. Avram, M. Management Contabil; Universitaria Publishing: Craiova, Romania, 2010; p. 135.

62. Castro, D.; Atkinson, R.D.; Ezell, S.J. Embracing the Self-Service Economy; Information Technology and Innovation Foundation: Washington DC, USA, 2010.

63. Boyer, R. Is a finance-led growth regime a viable alternative to Fordism? A preliminary analysis. Econ. Soc. 2000, 29, 111-145. [CrossRef]

64. Lavoie, M.; Stockhammer, E. Wage-Led Growth: Concept, Theories and Policies. Project Report for the Project "New Perspectives on Wages and Economic Growth: The Potentials of Wage-Led Growth"; International Labour Office: Geneva, Switzerland, 2012.

65. Stockhammer, E. Financialization, income distribution and the crisis. Investigación Económica 2012, 71, 39-70.

66. Schmitt, J. Why Does the Minimum Wage Have No Discernible Effect on Employment? Center for Economic and Policy Research: Washington, DC, USA, 2013.

67. Bartel, A.P. Training, wage growth, and job performance: Evidence from a company database. J. Labour Econ. 1995, 13, 401-425. [CrossRef]

68. Dunne, T.; Foster, L.; Haltiwanger, J.; Troske, K.R. Wage and Productivity Dispersion in U.S. Manufacturing: The Role of Computer Investment; No. 563; Institute of Labour Economics (IZA): Bonn, Germany, 2004.

69. Duncan, G. Unemployment and social exclusion in the European Union. J. Eur. Soc. 1999, 1, $139-167$.

70. Brown, C.; Gilroy, C.; Kohen, A. The effect of the minimum wage on employment and unemployment. J. Econ. Lit. 1982, 20, 487-528.

71. Brown, C. Minimum wage laws: Are They Overrated? J. Econ. Perspect. 1988, Summer, 133-145. [CrossRef]

72. CEDEFOP. Learning and Innovation in Enterprises; Research Paper No. 27; CEDEFOP: Luxembourg, 2012.

73. Dima, B.; Lobonţ, O.R.; Moldovan, N.C. Does the Quality of Public Policies and Institutions Matter for Entrepreneurial Activity? Evidences from the European Union's Member States. Panoeconomicus 2016, 63, 425-439. [CrossRef]

74. Pirtea, M.G.; Nicolescu, C.; Boțoc, C. Do Romanian Companies Follow Pecking Order Financing? Econ. Comput. Econ. Cybern. Stud. Res. 2014, 48, 1-15.

(C) 2019 by the authors. Licensee MDPI, Basel, Switzerland. This article is an open access article distributed under the terms and conditions of the Creative Commons Attribution (CC BY) license (http://creativecommons.org/licenses/by/4.0/). 